\title{
Sole Haemorrhages and Heel Horn Erosion in Dairy Cows: The Influence of Housing System on their Prevalence and Severity
}

\author{
By C. Bergsten and A. H. Herlin
}

Experımental Statıon, Swedısh Unıversity of Agnicultural Sciences, Skara and Department of Anımal Nutrition and Management, Swedish Unıversity of Agricultural Sciences, Alnarp, Sweden.

\begin{abstract}
Bergsten, $\mathrm{C}$ and A.H. Herlin. Haemorrhages of the sole and heel horn erosion in dairy cows: The influence of housing system on their prevalence and severity. Acta vet. scand. 19996, 37, 395-408. - Altogether $94 \%$ of the primiparous and $66 \%$ of the multiparous cows had haemorrhages of the sole at trimming 2-4 months after calving. Within cows, and independent of age and stall system, the lateral hind claws had higher scores of haemorrhages than the other claws. The primiparous cows had higher scores than the multiparous cows both in the tie-stalls and in the cubicles.

The palmar/plantar region of the claw capsule was divided into zones ("white line zones" and "sole zones"). For the multiparous cows the haemorrhage scores of the "white line zones" were higher among the cows housed in the cubicles than among those housed in the tie stalls. There was no difference between stall systems for haemorrhages of the "sole zones".

Heel horn erosion was absent or rare in the fore hooves of both the primiparous and multiparous cows in the tie-stalls. The cows in the cubicles had higher heel horn erosion scores in their fore hooves than the cows in the tie-stalls. The scores of the hind hooves were generally higher than those of the fore hooves in both systems. Heel horn erosions were reduced in association with the introduction of a footbath.

A higher incidence of lameness was observed in the cubicle system.
\end{abstract}

cubicles; foot disease; footbath; hoof trimming; lameness; laminitis.

\section{Introduction}

Healthy hooves are an important prerequisite for the welfare and productivity of dairy cows. Lameness due to hoof lesions is one of the most common disease problems in modern dairy production, and may lead to changes in the cows' behaviour, to reductions in their milk yield and fertility, and to a shortening of their productive life (Collick et al. 1989, Coulon et al. 1989, Manson 1989).

By tradition about $90 \%$ of Swedish dairy cows have been kept tied up, in either long or short stalls. However, today, Swedish animal welfare legislation and the tendency towards larger dairy units both favour the introduction of cubicle systems in which the cows are left free to move around; as a result most new dairy systems use cubicles. In a cubicle system the clinical signs of hoof diseases are more easily recognised than when the cows are kept tied up. Furthermore, any lesions may be more harmful because the diseased hooves are exposed to abrasion and pressure when the animal moves between the milking parlour and the feeding and resting areas (Maton 1987, David 1989). 
In Sweden the average annual incidence of lameness treated by veterinarians is about $3 \%$ (SHS 1994). However, their real incidence is certainly much higher, because hoof lesions is often treated by a hoof trimmer, or may even not be treated at all. In an investigation of presumably healthy cattle at a slaughterhouse only $26 \%$ of them had claws free of lesions, the most common of which were lesions associated with laminitis and heel horn erosion (Andersson \& Lundström 1981).

Laminitis (Pododermatitis aseptica diffusa) occurs in different forms and can be recognised retrospectively by the presence of haemorrhages of the sole horn. These lesions may develop into sole ulcer (Pododermatitis circumscripta), white line disease (Pododermatitis zona alba) or claw abscess (Pododermatitis septica; Nilsson 1966, Edwards 1982, Greenough 1985, Bergsten 1994b).

Heel horn erosion (Erosio ungulae) originates primarily from a dermatitis (Dermatitis interdigitalis or Dermatitis digitalis) resulting from an attack on the heel horn by opportunistic microorganisms (Peterse 1985, Toussaint Raven et al. 1985, Blowey 1994). Interactions between laminitis and heel horn erosion are also suggested (Greenough \& Vermunt 1991).

Many factors are involved in the aetiology of laminitis and heel horn erosion, including housing, feeding and management. The risk factors associated with laminitis are related primarily to environmental, nutrional and/or hormone changes during the period shortly before and after calving. However, the characteristic changes in the sole horn do not become apparent until before 2 months after the original injury, that is the period required for the newly formed, but damaged, horn to appear at the surface of the sole (Peterse 1980, Bergsten et al. 1986, Kempson \& Logue 1993).

The risk of heel horn erosion increases with the degree of contamination of the hooves with faeces (Bergsten \& Pettersson 1992). The risk therefore increases during the period of peak lactation, when cows produce large amounts of soft faeces because of high feed intakes. Minor lesions tend to heal spontaneously at the end of the lactation or when the animals are on pasture (Peterse 1985, Toussaint Raven et al. 1985, Maton 1987). Laminitis and heel horn erosion are most prevalent when the cows are housed during the winter, at peak lactation, and they are both easiest to diagnose as lesions of the hoof horn during the period between 2 and 4 months after calving (Thysen 1987).

The aim of the present investigation was to study the influence of 2 housing systems, tiestalls and cubicles, on the prevalence, severity, and location of sole haemorrhages and heel horn erosion in first calving heifers and older cows.

\section{Materials and methods}

\section{Environment}

The study was made at the University Research Station, Alnarp, during 3 consecutive years (1988/89-1990/91). The animals were housed in one barn which provided a section with tiestalls and a section with cubicles.

The tie-stall section had short stalls $(1.8 \mathrm{~m} \times 1.3$ $\mathrm{m})$ with concrete floors covered by rubber mats, and there were partitions between each cow and its neighbours. Each cow was tied with crossties and had a manger in front of its stall (Fig. 1a). Chopped straw ( $0.5 \mathrm{~kg}$ once daily) and sawdust ( $1 \mathrm{~kg}$ twice a day) were provided as bedding.

The cubicle section had 2 rows of cubicles, one on each side of a common manger. The size of the cubicle was $2.2 \mathrm{~m} \times 1.3 \mathrm{~m}$ with an extra space of $76 \mathrm{~cm}$ in the front for making rising easier. The cubicles had concrete floors covered by rubber mats and there was no edge in the rear (Fig 1b). Sawdust (3-4 kg at each occasion) was 

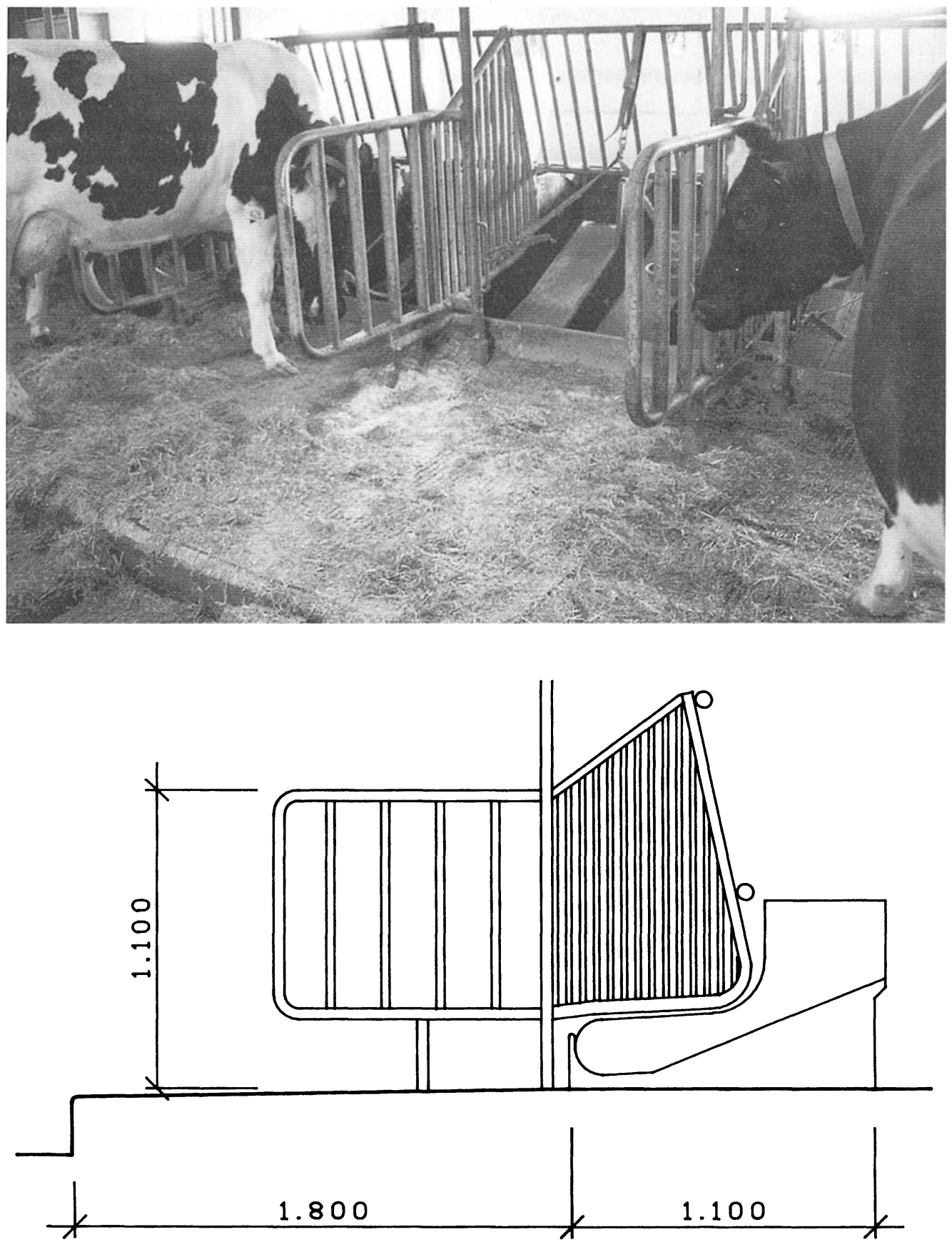

Figure 1a. The design of the tie-stalls. 

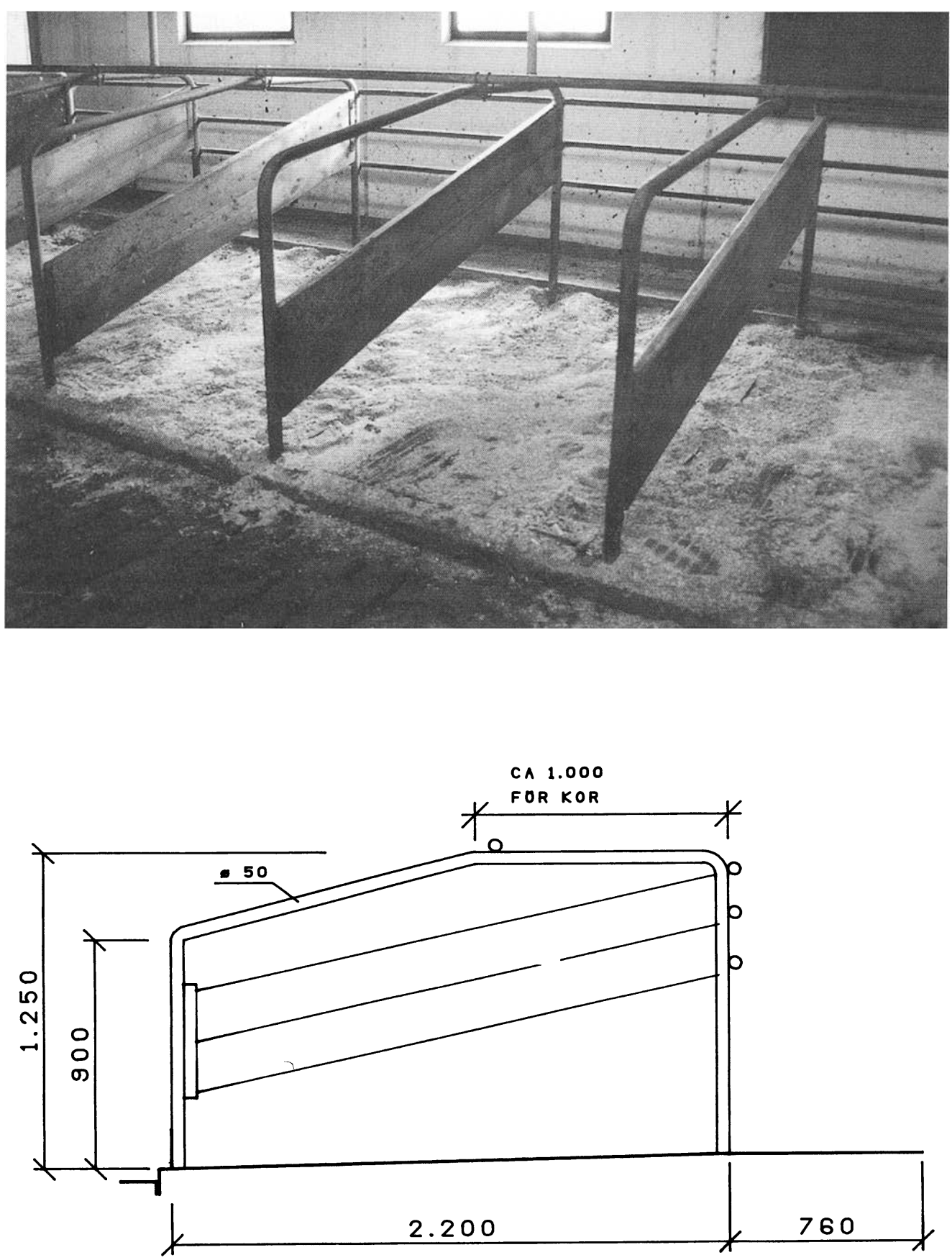

Figure $1 b$. The design of the cubicle stalls. 
Table 1. The diets fed to the primiparous and multiparous cows between 3 and 20 weeks of lactation, during the 3 years of the study ( $\mathrm{DM}=$ dry matter). Concentrates and silages were from computer-controlled feed carriers in the tie-stalls; in the cubicles all kinds of roughage were group-fed.

\begin{tabular}{|c|c|c|c|c|c|c|}
\hline \multirow[t]{2}{*}{ Diet } & \multicolumn{3}{|c|}{$\begin{array}{c}\text { Primıparous cows } \\
\text { Year } \\
\end{array}$} & \multicolumn{3}{|c|}{$\begin{array}{c}\text { Multiparous cows } \\
\text { Year } \\
\end{array}$} \\
\hline & 1 & 2 & 3 & 1 & 2 & 3 \\
\hline Grass hay, kg & 40 & 3.0 & 4.5 & ad lib. & 3.0 & ad lib. \\
\hline Grass sllage, kg DM & 2.0 & 3.0 & - & ad lib. & 3.0 & - \\
\hline Alfalfa sılage, $\mathrm{kg}$ DM & 4.0 & 3.0 & 4.0 & 5.0 & ad lib. & ad lib. \\
\hline Beet pulp silage, kg DM & - & - & - & - & - & 3 \\
\hline Barley straw, kg & - & - & 1 & - & - & 1 \\
\hline Dred molassed beet pulp, $\mathrm{kg}$ & - & - & 3.3 & - & - & - \\
\hline Concentrate mixture*, kg & 7.2 & 8.2 & 7.0 & 10.0 & 10.0 & 11.1 \\
\hline
\end{tabular}

* Grain $80 \%$ (barley $45 \%$, oats $45 \%$, dried molassed beet pulp $10 \%$ ), protein feed $20 \%$ (soya bean meal $50 \%$, rape seed meal $50 \%$.

provided twice a week as bedding. The alley ways were made of concrete slats $(120 \mathrm{~mm}$ slats with $40 \mathrm{~mm}$ slots). A short step of the floor in front of the manger was designed to prevent the anımals from defecating into the manger.

\section{Animals}

The cows were all born within the herd and were of the Swedish-Friesian breed. They were taking part primarily in a production study (Herlin 1994), for the purpose of which they had been divided into groups which were as similar as possible with respect to their sire, liveweight at breeding, expected time of calving and, for the multiparous cows, their milk production during the previous lactation. The animals in the present study were heifers and cows which were expected to calve during the autumn and early winter; the numbers included are shown in Tables 2 and 3.

Half the cows housed in the tie-stall section and half those in the cubicle section were assigned at random to a grazing group. They were allowed to graze during the daytime only from the beginning of May until the beginning of October. All the heifers had been on pasture during the summer before their first calving. The animals which were expected to calve during the early autumn were taken from the pasture to either the tie-stall section or the cubicle section of the barn 3 weeks before calving.

The primiparous and multiparous cows in the cubicle section were kept in 2 separate groups. In the course of the study several animals were culled, mainly as a result of mastitis and infertility. Any cows in the multiparous group which were culled in this way were replaced before the beginning of the following year by previously primiparous cows which had been housed in the same stall system.

\section{Diet and feeding regimens}

From 3 weeks before expected calving the animals were gradually adapted to the lactation diet. For all the animals the quantity of concentrates fed at calving (primiparous cows 3.6-4.1 $\mathrm{kg}$ /day, multiparous cows $5.0-5.5 \mathrm{~kg} /$ day) was half the quantity fed at peak lactation. The diets fed during weeks 3 to 20 of lactation are shown in Table 1 .

The cows in the tie-stalls were fed concentrates and silages from computer-controlled feed car- 
Table 2. Haemorrhages of the sole (= sole and white line zones) and mean weighted scores for the haemorrhages of the "white line zones" and "sole zones" for the medial and lateral claws of the fore and hind hooves of primiparous cows kept etther in tie-stalls or cubicles during year 1, 2 and 3. Significance between housing system: ${ }^{*}=\mathrm{p}<0.05$.

\begin{tabular}{|c|c|c|c|c|c|c|c|}
\hline & \multicolumn{2}{|c|}{ Year 1} & \multicolumn{2}{|c|}{ Year 2} & \multicolumn{2}{|c|}{ Year 3} \\
\hline & & Tie stalls & Cubıcles & T1e stalls & Cubicles & Tie stalls & Cubıcles \\
\hline \multicolumn{2}{|c|}{ Number of cows } & 18 & 16 & 12 & 12 & 12 & 14 \\
\hline \multicolumn{8}{|c|}{ "Sole haemorrhages" } \\
\hline \multicolumn{2}{|c|}{ Number of cows } & 17 & 14 & 10 & 12 & 12 & 14 \\
\hline \multicolumn{2}{|c|}{ Per cent of cows } & 94 & 88 & 83 & 100 & 100 & 100 \\
\hline \multicolumn{8}{|c|}{ "White line zones" } \\
\hline \multirow[t]{2}{*}{ Fore claws } & Medial & 0.3 & $1.8^{*}$ & 0.3 & 0.3 & 02 & $0.7^{*}$ \\
\hline & Lateral & 0.6 & 0.8 & 0.3 & 0 & 0.8 & 0.4 \\
\hline \multirow[t]{2}{*}{ Hind claws } & Medial & 1.0 & 0.8 & 0.3 & 0.3 & 0.6 & $0.1^{*}$ \\
\hline & Lateral & 3.3 & 2.9 & 1.1 & 0.9 & 2.6 & 2.8 \\
\hline \multicolumn{8}{|c|}{ "Sole zones" } \\
\hline \multirow[t]{2}{*}{ Fore claws } & Medıal & 3.2 & 1.3 & 0.7 & 1.1 & 0.3 & 1.1 \\
\hline & Lateral & 0.9 & 0.3 & 0.3 & 0.3 & 1.0 & 0.6 \\
\hline \multirow[t]{2}{*}{ Hind claws } & Medial & 1.8 & 0.3 & 0.3 & 0.8 & 0.3 & 0.8 \\
\hline & Lateral & 6.1 & 3.9 & 2.6 & 0.9 & 1.5 & 2.3 \\
\hline
\end{tabular}

Table 3. Haemorrhages of the sole (= sole and white line zones) and mean weighted scores for the haemorrhages of the "white line zones" and "sole zones" for the medial and lateral claws of the fore and hind hooves of multiparous cows kept either in tie-stalls or cubicles during year 1, 2, and 3. Significance between housing system: ${ }^{*}=\mathrm{p}<0.05,{ }^{* *}=\mathrm{p}<0.01,{ }^{* * *}=\mathrm{p}<0.001$.

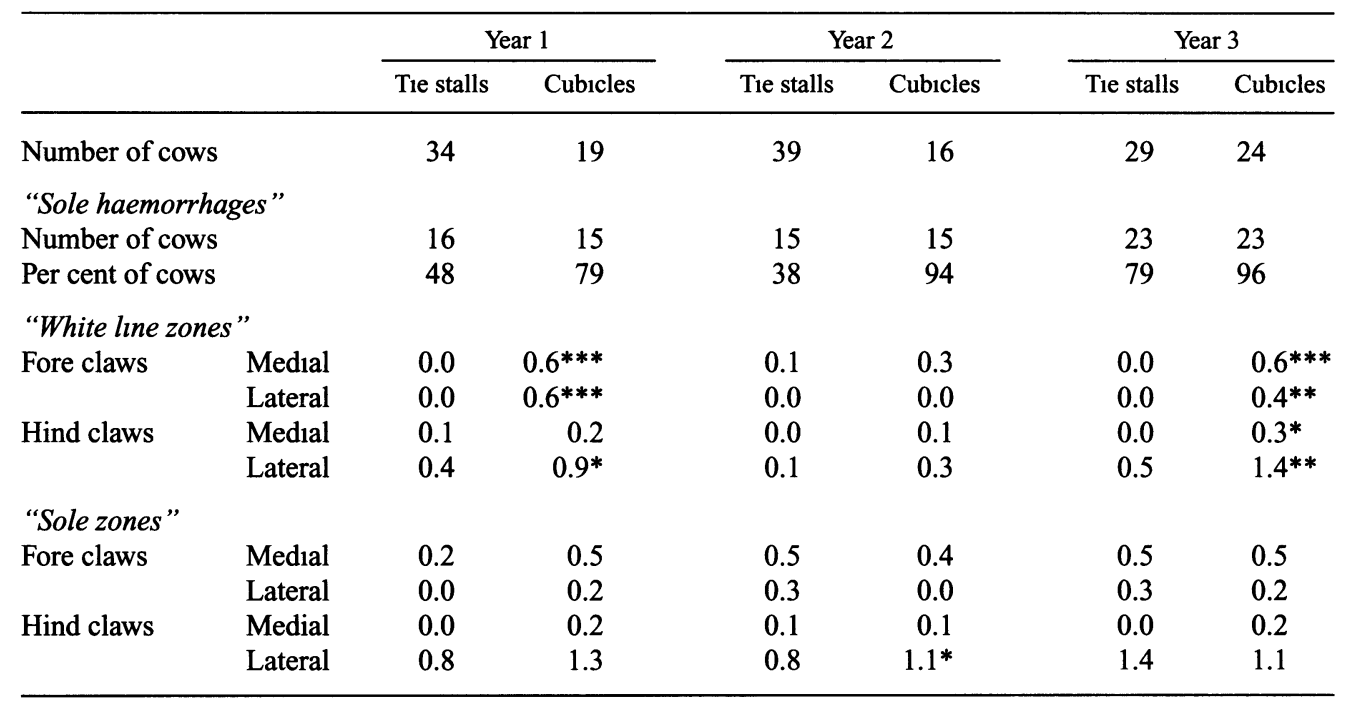


riers and they had free access to their mangers $24 \mathrm{~h}$ a day. All the primiparous cows and half the multiparous cows were fed roughage twice a day and concentrates 4 times a day; the other multiparous cows were fed roughage 4 times a day and concentrates 6 times a day. This difference in the feeding regimens for the multiparous cows formed part of the design of the production study, and it was not taken into consideration in the comparisons between the 2 housing systems in the present study.

The cows in the cubicles were provided with roughage in the common manger. Their concentrates were provided at computerised feeding stations, and the allowance was linearily correlated to the amount per $24 \mathrm{~h}$ and limited a cow's intake on any occasion to $2.1 \mathrm{~kg}$. They all had free access to their daily ration of roughage and concentrates.

\section{Management}

The cows were milked twice a day. The cows in the tie-stall section were milked in their stalls, and those in the cubicles were milked in a milking parlour. During the first year the primiparous cows in the cubicles were milked before the multiparous cows, but during the second and third years the multiparous cows were milked first. Pastured cows were all milked together in the milking parlour during grazing period. Considering all 3 years, the average daily milk yield during the first 20 weeks of lactation was 23.2 $\mathrm{kg}$ energy-corrected milk $(\mathrm{kg} \mathrm{ECM}=0.25 \times \mathrm{kg}$ milk $+12.2 \times \mathrm{kg}$ fat $+7.7 \times \mathrm{kg}$ protein) for the primiparous cows and $29.1 \mathrm{~kg}$ ECM for the multiparous cows. The details of the feeding and management of the cows and their production performance have been presented elsewhere (Herlin 1994).

Throughout the trial the cows' hooves were inspected and trimmed within 2 to 4 months after calving; the mean intervals between calving and trimming for the primiparous cows were:
84,101 , and 112 days in the first, second and third years respectively, and for the multiparous cows the corresponding intervals were 96,101 , and 106 days. In the second and third year the cows' hooves were also inspected and trimmed about one month before their expected calving. From November in the second year, the cows in the cubicles were made to use a footbath containing 5\% copper sulphate solution; they had to pass through the bath on their way to and from milking. Foot bathing was also performed at milking for cows in the tie-stall section while they were at pasture during the summer between the second and third years of the trial.

\section{Records of hoof lesions}

When the hooves were trimmed 2 to 4 months after calving all the claws were photographed by the technique described by Bergsten (1993). The photographs were evaluated at one occasion by the same 2 people, who had no knowledge of the age of the cows or the way in which they had been housed.

For the purposes of evaluation the sole of each claw was divided into 6 zones ( 1 to 6 ) according to an international recommendation (Fig. 2). For each of zones 1 to 5 , any haemorrhages of the horn of each claw were scored according to a five-point scale: $0=$ normal, $1=$ slight discolouration, 2 = moderate discolouration, 3 = severe discolouration and $4=$ exposed corium (sole ulcer). These scores were then weighted to take account of the relative severity of the different lesions as follows: $0=0,1=1,2=2,3=4$, and $4=8$, according to Greenough \& Vermunt (1991). The scores for zones 1 to 3 (lamellar horn and wall = "white line zones") were added together, as were the scores for zones 4 and 5 ("sole zones"). This way of scoring is somewhat diverging from that earlier used by Bergsten (1994a) and Bergsten \& Frank (1995a and b); in these trials the haemorrhages of the whole palmar/plantar region (sole and white line) 


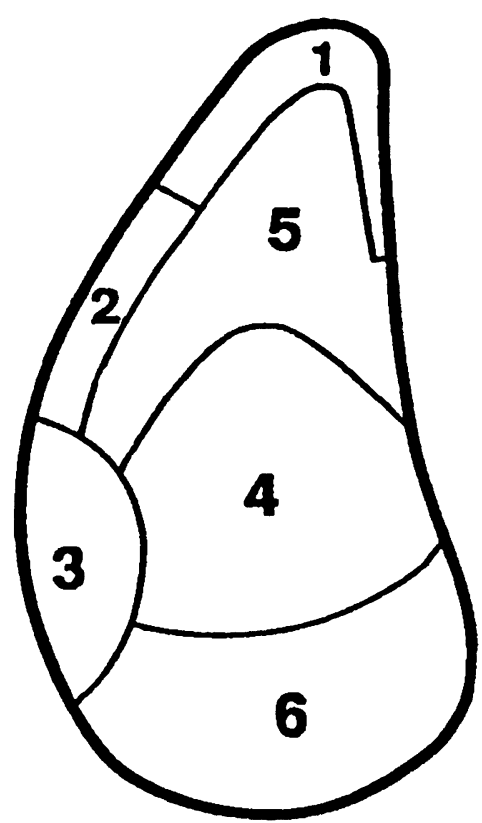

Figure 2. Zones of the sole (palmar/plantar regions of the claw capsule) according to Greenough \& Vermunt (1991). Zone 1 white zone at the toe, zone 2 abaxial white zone, zone 3 abaxial wall-bulb junction, zone 4 sole-bulb junction, zone 5 apex of the sole, zone 6 bulb.

were evaluated as an entirety and the scores were not adjusted according to severity.

Erosions of the heel horn in zone 6 were scored for both claws on a four-point scale: $0=$ no erosion, 1 = slight erosion, 2 = moderate erosion and $3=$ severe erosion, according to Bergsten \& Pettersson (1992). These scores were not modified by any weighting procedure.

\section{Statistical analysis}

The scores for the different lesions, recorded from the primiparous and multiparous cows housed in the 2 different systems were analysed by the Kruskal-Wallis test (Kruskal \& Wallis 1952) using Statistical Analysis Systems (SAS Institute Inc. 1987).

\section{Results}

Haemorrhages of the "sole zones" and "white line zones"

The scores for the haemorrhages recorded during the 3 years in the primiparous and multiparous cows housed in the tie-stalls or cubicles are summarized in detail in Table 2 and 3.

The prevalence of haemorrhages was high. Thus altogether 79 out of $84(94 \%)$ of the primiparous cows and 107 out of $161(66 \%)$ of the multiparous cows had haemorrhages of the sole at the trimming.

In the cows kept in the tie-stalls, the haemorrhage scores in the "white line zones" (zones 1 to 3 ) of the fore claws were higher in the primiparous cows than in the multiparous cows, and these differences were even more pronounced in the hind claws. The haemorrhage scores of the "white line zones" of the primiparous cows kept in the cubicles were also higher than those of the multiparous cows except for a slightly higher score in the medial hind claws of the multiparous cows in the third year. The scores of haemorrhages of the "sole zones" (zones 4 and 5) were as well higher among the primiparous cows except for the medial fore claws the third year in the tie stalls, and of the lateral hind claws the second year in the cubicles.

The lateral hind claws had much higher scores of haemorrhages than the other claws both within the primiparous and within the multiparous cows; the highest scores during the study were found in those lateral hind claws of the primiparous cows.

For the primiparous cows there were no significant differences between the scores of haemorrhages in any region of the fore or hind claws of the cows housed in the 2 types of accommodation except for a higher score of the "white line zones" of medial fore claws in the cubicles first and third year and for a lower score of the "white line zones" of the medial hind claws in the cubicles during third year $(\mathrm{p}<0.05)$. 
For the multiparous cows the haemorrhage scores recorded in the "white line zones" were higher in all 3 years among the cows housed in the cubicles than among those housed in the tiestalls. In the first and third years most of these differences were statistically significant.

The haemorrhage scores recorded in the "sole zones" of all the claws of the multiparous cows were slightly, but not significantly, higher during the first year in the cows kept in cubicles than in those kept in tie-stalls. In contrast, during the second and third years, the scores for haemorrhages in the fore and hind claws were equal or higher in the cows kept in the tie-stalls, except in the cases of the lateral hind claws in the second year $(p<0.05)$ and the medial hind claws in the third year. However, with one exception none of these small differences were statistically significant.

There were some differences between the results observed for the 3 years. In primiparous cows the score for haemorrhages in the "sole zones" of the medial fore claws and in the lateral hind claws of the cows kept in the tie-stalls were highest during the first year $(p<0.05)$. For the cows in the cubicles the score for haemorrhages of the "white line zones" of the fore claws and the lateral hind claws was lowest during the second year $(p<0.05)$.

For the multiparous cows kept in the tie-stalls, the score for haemorrhages of the "sole zones" of the lateral fore claws was lowest during the first year and lateral hind claws scored highest during the third year $(p<0.05)$. The lovest score for haemorrhages of the "white line zones" was recorded in the second year in the cows kept in the cubicles of the medial $(p<0.05)$ and lateral $(p<0.01)$ hind claws, and in the tie-stalls of the lateral hind claws $(p<0.05)$.

\section{Heel horn erosion}

The scores for heel horn erosion during the 3 years are shown in Table 4.
Erosions of the heel horn were nearly absent in the fore claws of both the primiparous and multiparous cows kept in the tie-stalls throughout the trial. The primiparous cows kept in the cubicles mostly had significantly higher scores in their fore claws than the cows in the tie-stalls, and during the first year the multiparous cows kept in the cubicles also had significantly higher scores than the cows kept in the tiestalls.

The scores of the hind claws were generally higher than those of the fore claws. The only significant difference between stall systems was a higher score among the multiparous cows kept in the tie-stalls the second year; the difference in the opposite direction among the primiparous cows was not significant

There was a significant reduction in the scores of heel horn erosion between the first, and the second years of the fore and hind claws of the multiparous cows kept in the cubicles and of the hind claws among the primiparous cows in the tie-stalls $(p<0.05)$. There was a similarly marked reduction between the second and third years in the scores of heel horn erosion of the hind claws of the multiparous cows kept in the tie-stalls $(p<0.001)$ and of the fore and hind claws $(p<0.01)$ of the primiparous cows kept in cubicles. No association between scores of haemorrhages and heel horn erosion were found.

\section{Clinical lameness}

During the 3 years study $9 \%(n=13)$ of the animals in the tie stalls and $18 \%$ of the animals $(n=18)$ in the cubicles were observed being lame. Among the primiparous cows $14 \%$ were lame and among multiparous cows $12 \%$. Seventyone percent $(n=22)$ of these cases were revealed within the first months of lactation and $45 \%(n=14)$ during the first year. 3 of the lame cows were affected with interdigital phlegmon (Phlegmona interdigitalis) - all of them in the 
Table 4. The mean scores for heel erosion (zone 6) on the fore and hind hooves of primiparous and multıparous cows kept either in tie-stalls or cubicles during year 1, 2, and 3. Significance between housing systems: $*=\mathrm{p}<0.05,{ }^{* *}=\mathrm{p}<0.01,{ }^{* * *}=\mathrm{p}<0.001$.

\begin{tabular}{lcccccccc}
\hline & \multicolumn{2}{c}{ Year 1 } & & \multicolumn{2}{c}{ Year 2 } & & \multicolumn{2}{c}{ Year 3 } \\
\cline { 2 - 3 } & Tie stalls & Cubıcles & & Tie stalls & Cubıcles & & Tie stalls & Cubıcles \\
\hline Primiparous cows & 18 & 16 & & 12 & 12 & & 12 & 14 \\
Fore claws & 0.0 & $0.6^{* * *}$ & & 0.2 & $0.8^{*}$ & & 0.0 & 0.0 \\
Hind claws & 0.8 & 0.8 & & 0.3 & 0.8 & & 0.1 & 0.1 \\
Multiparous clows & 34 & 19 & & 39 & 16 & & 29 & 24 \\
Fore claws & 0.0 & $0.4^{* * *}$ & & 0.0 & 0.1 & & 0.0 & 0.0 \\
Hind claws & 0.7 & 0.7 & & 0.8 & $0.2^{*}$ & & 0.1 & 0.3 \\
\hline
\end{tabular}

cubicle system. Thirteen animals had sole ulcer; 8 out of $84(9.5 \%)$ among the primiparous cows an 5 out of $161(3.1 \%)$ among the multiparous cows. There was no difference in the incidence of sole ulcer between the stall systems; 8 out of $144(5.5 \%)$ in the tie stalls and 5 out of $101(5.0 \%)$ in the cubicles. The other 15 lame cows had sole haemorrhages recorded at trimming; 5 out of 144 (3.5\%) in the tie stalls and 10 out of $101(9.9 \%)$ in the cubicles.

\section{Discussion}

The high prevalence of the haemorrhages of the sole horn indicates that events related to calving highly predispose for haemorrhages of the corium (laminitis) as earlier has been reported (Peterse 1980, Bergsten et al. 1986, Bergsten \& Frank 1995b). On the other hand, the severity scores for the haemorrhages of the cows kept in the 2 systems of housing were relatively low, possibly owing to the preventive effects of regular hoof trimming, adequate feeding and a satisfactory environment (Peterse 1980, Manson \& Leaver 1988, Enevoldsen et al. 1991). Nevertheless, significant variations in the location and severity of the lesions were revealed by the detailed recording system used.
Haemorrhage of the "sole zones" and "white line zones"

In both systems, over the 3 years, the haemorrhage scores were higher among the primiparous cows than among the multiparous cows. This result is in accordance with earlier observations of cows kept in different housing systems in Denmark (Thysen et al. 1981), and with an earlier Swedish study in which the primiparous cows kept in tie-stalls had a higher score of haemorrhages of the sole than the multiparous cows (Bergsten 1994a); there have also been several reports that when heifers are introduced into cubicles when close to calving they suffer a high incidence of laminitis, haemorrhages of the sole, and sole ulcers (David 1989, Greenough \& Vermunt 1991, Singh et al. 1993). The higher scores recorded in the lateral hind claws are also in accordance with the results of several other studies (Andersson \& Lundström 1981, Greenough \& Vermunt 1991), and furthermore, it is well known that most clinical signs are the result of lesions in the lateral claws (Russell et al. 1982, Livesey \& Fleming 1984, Thysen 1987).

It has been shown that a feeding regimen which can be supposed to result in fluctuations in the rumen $\mathrm{pH}$ can increase the prevalence of haemorrhages of the sole (Bergsten 1994a). In the 
present study no account was taken of the possible nutritional differences between the cows kept in the tie-stalls and those kept in the cubicles. However, the diets fed to them, and to the primiparous and multiparous cows, were quite similar. The fact that the period of adaptation may have been too short for the first calvers, because they would have been unfamiliar not only with the lactation diet, but also with the milking routines, management system and the new social interactions with older cows as proposed by Leonard (1994) may explain some of the differences observed between the primiparous and multiparous cows in both systems of housing. Also a high culling rate among primiparous cows might have selected for less susceptible multiparous cows.

Among the multiparous cows the scores of the "white line zones" were consistently higher in the cubicle system than in the tie-stalls, which is in accordance with results presented by Rowlands et al. (1983) who found a higher incidence of white line lesions in cubicle systems and in strawyards where the cows were freely moving compared to "cowsheds". On the other hand no uniform pattern was found in the present study between the 2 stall systems in the preva-lence of the haemorrhages of the "sole zones", also in agreement with the results of Rowlands et al. (1983). They thus found no difference in the incidence for sole ulcer between cubicles with concrete yard and "cowsheds". The difference between the "sole zones" and the "white line zones" might be refered to a high pressure load of the weight bearing wall of the white line area when the animals walk on a conc-rete floor as proposed by Vermunt (1990). On an uneven floor this situation might be accentuated because of torsial forces (David 1986); Murphy's \& Hannan's conclusion (1986) that slatted flooring is the primary inciting cause of white line lesions corresponds with this hypothesis. It is also interesting that ab- scesses of the white line and white line separation have been reported by Russell et al. (1982) to be the most common lesions in the claw horn to be treated by veterinarians in England, where loose housing systems are much more common than in Sweden.

\section{Heel horn erosion}

The absence of heel horn erosions in the fore hooves of all the cows kept in the tie-stalls was probably a result of the dry, clean environment provided at the front of the cows by this housing system. Their presence in the hind hooves was probably due to the dirtier and wetter conditions at the rear of the cows; the damp conditions have except for contributing to a higher exposure of pathogens for the hooves also been found to reduce the dry matter content of the hoof horn, thus reducing the resistance of the horn to attack by the chemical and microbiological components of the faeces (Bergsten \& Pettersson 1992).

In contrast heel horn erosions were almost as common in the fore claws of the cows kept in the cubicles as in their hind hooves, presumable because the conditions at the front and back of the cows were more nearly similar in this housing system. In a Danish study (Thysen 1987), heel horn erosions were constantly more common in the hind hooves of cows kept in cubicles than of cows kept in tie-stalls, whereas in the present study the scores were only higher in the cubicle system during year 2 for primiparous cows; in fact the scores were significantly higher in the tie-stalls during year 2 for the multiparous cows. The difference between our study and Thysen's may be partly due to the fact that in Denmark tie-stalls are often equipped with electric cow-trainers, which may have resulted in relatively cleaner conditions for the hind hooves. Moreover, in the present study the section of the barn with the cubicles had a slatted floor. The cows in the cubicles might have 
had more heel horn erosions if, instead of the slatted floor, there had been scraped alleys; Thysen (1987) reported a higher incidence of the disease in cows kept in such accommodation than in cows kept in barns with slatted floor.

\section{Between year variations}

There were differences between the results for the 3 years in terms of the prevalence of sole haemorrhages. They may have been due to unrecognised differences in the quality of the roughage fed during the 3 years. At least for the primiparous cows the scores of haemorrhage was higher during the first year than during the other 2 years, which indicates an effect also of the extra trimming performed before calving from the second year; Peterse (1980) during a 3 year study found a gradual improvement of claw health, which was explained by a higher attention paid to the animals during the study. In general there was a clear tendency for the prevalence of the heel horn erosions to be greater during the first year of the trial. The decline in the later years may have been related to the introduction of footbaths, the first in November of the second year for all the cows housed in the cubicles, and the second during the summer season between the second and third years for the pastured cows kept in the tiestalls. The beneficial effect of foot bathing for the prevention of infectious hoof diseases is well documented (Peterse 1980, Toussaint Raven et al. 1985, Arkins et al. 1986). The results shown in Table 4 can be explained on this basis as far as all the animals kept in the tie-stalls are concerned, and as far as the multiparous cows kept in the cubicles. However, the reduction in heel horn erosions observed between the second and third years among the primiparous cows kept in the cubicles, would also have been expected between the first and second years, as for the multiparous cows. The delay in the re- duction may have been due partly to the fact that during the second and third years the primiparous cows were milked after the multiparous cows, and thus used a footbath which was already contaminated with faeces, and partly to the fact that the reduced microbiological pressure in the barn during the third year may have helped to prevent the infection.

\section{Clinical findings}

A higher incidence of clinical lameness was found in the cubicle system. Also (Thysen 1987) found a higher incidence of hoof diseases treated by veterinarian in the cubicles, while the prevalence of subclinical laminitis disorders revealed at trimming was more equally distributed between housing systems. The degree of lameness was not evaluated in the present study. However, the higher frequency of sole ulcer in primiparous lame cows corresponded with a higher severity score in all primiparous cows. The lesions of heel horn erosion were not severe and therefore not considered to be associated with lameness.

\section{Conclusions}

The most prominent differences between the 2 housing systems were higher scores of haemorrhage of the "white line zones" of the multiparous cows in the cubicle system than in the tie stalls and lower scores of heel horn erosion of the fore claws of the animals in the tie stalls than in the cubicles. Also the incidence of clinical lameness was higher in the cubicle system than in the tie stalls.

The practical importance of the results is that the negative enviromental influence of the cubicle system should be reduced by a better design of the floors used for walking and standing. The floors should be soft, comfortable and clean at the feeding area. With separate, individually designed feeding stalls equipped with rubber mats these aimes can be achieved. 


\section{Acknowledgement}

The investigation was supported by the Swedish Council for Forestry and Agricultural Research and by the Swedish Farmers' Foundation for Research.

\section{References}

Andersson L, Lundström $K$ : The influence of breed, age, body weight and season on digital diseases and hoof size in dairy cows. Zbl. Vet. Med. A 1981, 28, 141-151.

Arkins S, Hannan J, Sherington $J \cdot$ Effects of formalin footbathing on foot disease and claw quality in dairy cows. Vet. Rec. 1986, 118, 580-583.

Bergsten C: A photometric method for recording hoof diseases in cattle, with special reference to haemorrhages of the sole. Acta vet. scand. 1993, 34, 281-286.

Bergsten C: Haemorrhages of the sole horn of darry cows as a retrospective indicator of laminitıs: An epidemiological study. Acta vet. scand. 1994a, 35, 55-66.

Bergsten C. Treatment of specific digital lesions. Proc. VIII Int. Symp. Disord. Ruminant Digit \& Int. Conf. Bovine Lameness, Banff, Canada, 1994b, pp. 58-67.

Bergsten C, Andersson L, Wiktorsson H: Effect of feeding intensity at calving on the prevalence of subclinical lamınitis. Proc. V Int. Symp. Disord. Rumınant Digit, Dublin, Ireland, 1986, pp. 34-38.

Bergsten $C$, Frank $B$. Sole haemorrhages in tied heifers in early gestation as an indicator of laminitis: Effects of diet and flooring. 1995a, in manuscript

Bergsten C, Frank $B$. Sole haemorrhages in tied primiparous cows as an indicator of periparturient laminits: Effects of diet, flooring and season. 1995b, in manuscript.

Bergsten C, Pettersson $B$. The cleanliness of cows tied in stalls and the health of their hooves as influenced by the use of electric trainers. Prev. Vet. Med. 1992, 13, 229-238.

Blowey RW: Studies on the pathogenesis and control of digital dermattis. Proc. VIII Int. Symp. Disord. Rumınant Digit \& Int. Conf. Bovine Lameness, Banff, Canada, 1994, pp. 168-173

Collick DW, Ward WR, Dobson $H$ Associations between types of lameness and fertility. Vet. Rec. 1989, 125, 103-106.

Coulon JB, Landals E, Garel JP: Pathologie et productıvité de la vache laitıère: interrelatıons à l'échelle de la lactation (Relationships between pathological events and productivity of milk cow on a full lactation period). Ann. Rech. Vet. 1989, 20, 443-459. (In French).

David GP: The influence of building design and management practices on lameness in heifers and cows. Proc. Brit. Cattle Vet. Assoc. 1984-85, Windermere, UK, 1986, pp. 155-159.

David GP: Epidemıological factors associated with a high incidence of sole ulcer and white line disease in darry cattle. Proc. Society Vet. Epidem. Prev. Med., Exeter, UK, 1989, pp. 149-158.

Edwards GB: Acute and subacute laminitis in cattle. Vet. Ann. 1982, 22, 99-106.

Enevoldsen C, Gröhn YT, Thysen I: Sole ulcers in dairy cattle: Association with season, cow characteristics, disease, and production. J. Dairy Sc1. 1991, 74, 1284-1298.

Greenough $P R$ : The subclinical laminitis syndrome. Bovine Pract. 1985, 20, 144-149.

Greenough PR, Vermunt JJ: Evaluation of subclinical laminitis in a dairy herd and observations on associated nutritional and management factors. Vet. Rec. 1991, 128, 11-17.

Herlin AH: Effects of tie-stalls or cubicles on dary cows in grazıng or zero grazıng situations. Thesis, Swedish Univ. Agr. Sc1., Uppsala, Sweden, 1994.

Kempson SA, Logue DN: Ultrastructural observations of hoof horn from dairy cows: changes in the white line during the first lactation. Vet. Rec. 1993, 132, 524-527.

Leonard FC: Effect of different housing on behaviour and foot lesions in Friesian heifers. Vet. Rec. 1994, 134, 490-494.

Livesey CT, Fleming $F L \cdot$ Nutritional influences on laminitis, sole ulcer and bruised sole in Friesian cows. Vet. Rec. 1984, 114, 510-512.

Manson FJ: Lameness and cattle welfare - a case study. Technical report. Dairy Res. Unit, Univ. Wales, 1989, p 87.

Manson FJ, Leaver JD: The influence of dietary protein intake and of hoof trimming on lameness in dairy cattle. Anım. Prod. 1988, 47, 191-199.

Maton $A$. The influence of the housing system on claw disorders with darry cows. In: Cattle Housing Systems, Lameness and Behaviour. Eds. HK Wierenga and DJ Peterse. Martınus Nijhoff Publishers, Dordrecht, the Netherlands, 1987, pp. 151-159.

Murphy PA, Hannan J Effects of slatted flooring on claw shape in intensively housed fattening beef 
cattle. Proc. V Int. Symp. Disorders Ruminant Digit, Dublin, Ireland, 1986, pp. 2-7.

Nulsson SA - Recent opinions about cause of ulceration of the hoof in cattle. Nord. Vet.-Med. 1966, $18,241-252$.

Peterse DJ . De beoordeling van de runderklauw op basis van het optreden van zoollaesies (Judgement of bovine claws by the occurrence of sole lesions). Thesis, Rijksuniv., Utrecht, the Netherlands, 1980. (In Dutch).

Peterse DJ. Laminitıs and interdigital dermatitis and heel horn erosion. An European perspective. In The veterinary clinics of North America: Food Animal Practice, Bovine Lameness and Ortoped1cs, vol. 1. Eds. D Ramanauskas and JG Ferguson. W.B. Saunders Company, Philadelphia, USA, 1985, pp. 83-91.

Rowlands GJ, Russell AM, Willams LA. Effects of season, herd size, management system and veterinary practice on the lameness incidence in dairy cattle. Vet. Rec. 1983, 113, 441-445.

Russell AM, Rowlands GJ, Shaw SR, Weaver AD Survey of lameness in British dairy cattle. Vet. Rec. 1982, 111, 155-160.

SAS Institute Inc SAS/STATTM - Guide for personal computers. Version 6. Edition, Cary, NC, USA, 1987.

SHS. Årsstatıstık ınklusıve djurhälsovård (Annual report of anımal health). SHS Swedish Ass Anım. Breed. Prod., Eskilstuna, Sweden, 1994. Report 174.

Singh SS, Ward WR, Lautenbach K, Murray RD Behaviour of first lactation and adult dairy cows while housed and at pasture and its relationship with sole lesions Vet. Rec. 1993, 133, 469-474.

Thysen I Foot and leg disorders in dairy cattle in different housing systems. In: Cattle Housing Systems, Lameness and Behaviour. Eds. HK Wierenga and DJ Peterse. Martinus Nijhoff Pub- lishers, Dordrecht, the Netherlands, 1987, pp. 166-178.

Thysen I, Buchwald E, Smedegaard $H H \cdot$ Skader og sygdome i malkekoens klove (Claw diseases of dairy cattle). Natl. Inst. Anim. Sci., Copenhagen, Denmark 1981. Report 515, pp. 49-72. (In Dan1sh).

Toussaint Raven E, Haalstra RT, Peterse DJ Cattle footcare and claw trimming. Farming press, Ipswich, UK, 1985.

Vermunt $J J$ Lesions and structural characteristics of dairy heifers in 2 management systems. M.V.Sc1 Thesıs, Unıv Sask., Saskatoon, Canada, 1990.

\section{Sammanfattning \\ Inverkan av två ollka stallsystem på prevalens och grad av sulblodningar och klovröta hos mjolkkor}

Vid klövverknıng 2-4 månader efter kalvnıng hade $94 \%$ av förstakalvare och $66 \%$ av äldre kor sulblodnıngar Oberoende av laktatıonsnummer och stallsystem hade ytterklovvarna bak högre sulblödnıngspoäng än óvriga klövhalvor. Förstakalvare hade högre blödnıngspoäng än àldre kor 1 båda stallsystemen. Klòvsulans yta indelades 1 zoner ("vita linjen" och "sulytan"). Hos äldre kor var poängen 1 "vita lınjen" hogre hos kor 1 lösdriftsystemet an hos de uppbundna djuren. För "sulytan" sågs ingen skıllnad mellan de båda stallsystemen

Varken hos förstakalvare eller äldre kor 1 det uppbundna systemet förekom någon klövröta på framklövarna annat än undantagsvis Framklövarna hade högre klövrötepoäng 1 lösdrıftssystemet. Bakklövarna hade 1 allmänhet högre poäng än framklövarna 1 båda systemen Klövrötan minskade i samband med att fotbad infördes.

En högre incıdens klinısk hälta observerades 1 lösdrıftsystemet.

(Received June 26, 1995, accepted June 14, 1996).

Reprints may be requested from: C. Bergsten, Experımental Statıon, Swedish Unıversity of Agricultural Sciences, PO.Box 234, S-532 23 Skara, Sweden. Fax: +46 (0) 511 67134, e-mail: christer-bergsten@fg.slu.se 